\title{
NURİ BİLGE CEYLAN VE YAVAŞ SİNEMA
}

\author{
Kurtuluş Özyazıcı
}

\begin{abstract}
Öz
Son yıllarda adları daha sık telaffuz edilen yavaş filmler, 2010'larla birlikte tanımlanmaya başladı, sahip oldukları ortak özellikler belirlenmeye çalışıldı. Uzun çekimlerin yer aldığı, sabit kameranın baskın olduğu, genelde suskun karakterlere sahip yavaş filmler, bir film türü olmaktan çok bir tarz olarak özelikle festivallerde izleyicinin karşısına çıkmaktadır. Gerçekçi film kuramlarıyla ilişkilendirilen ve Béla Tarr, Tsai Ming-liang gibi yönetmenlerin filmlerinin ilk sıralara yazıldığı yavaş filmler listesinde Nuri Bilge Ceylan'ın filmleri de yer almaktadır. Bu yazıda yavaş sinema tartışmalarından yola çıkarak Nuri Bilge Ceylan'ın filmleri öykü ve söylem açısından incelenmiş, filmlerinin yavaş sinemaya ne oranda dâhil olduğu tartışılmıştır.
\end{abstract}

Anahtar Sözcükler: Yavaş sinema, Nuri Bilge Ceylan, uzun çekim, düşündüren sinema, suskunluk. 


\title{
NURİ BİLGE CEYLAN AND SLOW CINEMA
}

\begin{abstract}
Slow cinema has gradually risen to prominence over the past decade as a distinct cinematographic form with its own set of common characteristics. Often associated with Realist Film Theories and the work of such directors as Béla Tarr and Tsai Ming-liang, slow cinema is a style rather than a genre, one marked by long takes, static camera angles, and silent characters. Through a discussion of the nature of slow cinema and an analysis of narrative and discourse in the films of Turkish director Nuri Bilge Ceylan, this study explores the extent to which Ceylan's films may be categorized as part of slow cinema.
\end{abstract}

Keywords: Slow movies, Nuri Bilge Ceylan, long take, contemplative cinema, silence. 


\section{Giriş}

Pek çok kişi arkadaş sohbetlerinde bir filmden bahsederken "güzel ama biraz yavaş" kalıbını kullanmıştır. Bu söz aslında beğendiğimiz ama birine önerirken klasik anlatı sinemasından farklı olduğu için onu uyardığımız bir ifadedir. Nuri Bilge Ceylan 2018 yllındaki bir söyleşide şöyle der: "Bir filmi yaptığımda bana hızlı olmuş geliyor. Sonra bakıyorum yazılanlara yine yavaş diyorlar. Benim iç tempom yavaş herhalde" (Kolver, 2018). Hasan Akbulut, Ceylan sinemasının aksiyonun olmadığı bir yavaşlıkta, günlük yaşamın sıradanlıklarını anlatan yalınlığıyla düşünmeyi talep eden bir sinema önerdiğini ve bunun kimilerine çok "sıkıcı" gelebileceğini söyler (2005, s. 10). Ceylan da Üç Maymun (2008) filminin kurgu günlüğüne düştüğü notlarla bu görüşe katılır gibidir: "Basık tavanlı küçük bir ev, iç mekânlar ve karanllk köşelerle, klostrofobik, seyri zor bir film olacak galiba" (Ceylan, 2008, s. 30).

Sinemanın son yıllarda birbirinden gittikçe farklılaşan iki ayrı kolda ilerlediği söylenebilir. Bunlardan ilki Holywood'un başını çektiği klasik anlatı sineması olarak tanımlanabilecek filmlerdir. Bu filmler gittikçe daha fazla hareket (aksiyon) içerir, çekim uzunlukları gittikçe kısalır. Gözümüz, bazen iki bazense saniyede bir farklı görüntüyle karşılaşabilmektedir. Diğer kol ise "sanat sineması" denilen klasik anlatı sinemasına karşı duruş olarak görülebilecek "festival filmleri"dir. Bunlar da gittikçe daha uzun çekimlere, daha az diyaloğa sahip olmaktadır. Klasik anlatı sinemasına alışkın izleyiciyi zorlayan bu filmler diğerleriyle karşılaştırıldığında epeyce yavaş ilerler. "Yavaş sinema" olarak da tanımlanabilen bu filmler bir süredir sinema yazarlarının ve akademisyenlerin odağında yer almaktadır. En belirgin temsilcileri Béla Tarr, Tsai Ming-liang, Lav Diaz gibi isimlerin olduğu, Andrei Tarkovski, Theo Angelopoulos gibi yönetmenlerin de dâhil edildiği yavaş sinemada Nuri Bilge Ceylan'ın da adı geçmektedir. Bu çalışma, yavaş sinema kavramının tarihçesine değinip yavaş sinemanın temel özelliklerini belirlemeyi ve Nuri Bilge Ceylan'ın filmlerinin yavaş sinemaya ne oranda dâhil olduğunu tartışmayı amaçliyor.

Bu makale, Ankara Üniversitesi Sosyal Bilimler Enstitüsü Radyo Televizyon ve Sinema Yüksek Lisans Programında 2019'da yazmış olduğum aynı adlı yüksek lisans tezinden üretilmiştir. Tezin danışmanı Doç. Dr. Ali Karadoğan'a katkıları ve desteği için çok teşekkür ederim. 


\section{Yavaş Sinema Tartışmalarının Tarihçesi}

2003 yllında 46. San Francisco Film Festivali kapsaminda Fransiz film eleştirmeni Michel Ciment, sinemanın o günkü durumunu gözler önüne seren bir konuşma yapar. Günümüz sinemasını değerlendiren Ciment'a göre ticari salonları "göz boyayan görüntülerle süslü aşırı gürültülü filmler" işgal etmektedir (2003a). Ciment, konuşmasının yavaş sinemayı ilgilendiren ve yavaş sinema tartışmalarının habercisi sayılabilecek bölümünde, Amerikan sinemasının (istisnalar olmak kaydıyla) bilgisayar oyunları mantığıyla çekilmeye başladığını belirtir ve Geoff King'in 2002 tarihli New Hollywood Cinema başlıklı kitabında karşılaştırdığı ortalama çekim uzunluklarına vurgu yaparak sinema seyircisinin sabırsızlaşmasının ortalama çekim uzunluğunu düşürdüğünü söyler (2003a). Ciment'a göre;

[...] sabırsız televizyon ve sinema seyircisi, görüntü ve ses bombardımanına tutulmuş filmler talep ederken bu teknoloji fetişizmine tepki gösteren bazı yönetmenler daha yavaş ve düşündüren filmler çekmeyi tercih etmiştir. Filmlerinde teknolojiyi çok iyi kullanan Stanley Kubrick'in klasik Hollywood sinemasinin panzehiri sayılan 2001: Uzay Yolu Macerası (2001: A Space OdYsseY, 1968), Barry Lyndon (1975) ve Gözü Tamamen Kapalı (Eүes Wide Shut, 1999) filmleri kışkırtıcı bir yavaşlığa nasıl sahipse bu yönetmenler de olaylara odaklanmaktan çok karakterlerinin içinde bulundukları durumu anlatan filmler çekmeyi tercih etmektedir (2003a).

Michel Ciment'ın bu konuşmasından beş yll sonra Mathew Flanagan "16:9" adlı bloğunda günümüz sinemasında yavaşlığın estetiğine odaklanır. ${ }^{2}$ Ona göre "çağdaş Amerikan sinemasındaki hızlanmaya tepki olarak pek çok yönetmen daha yavaş filmler çekmeye başlamıştır ve bu filmlerin bazı ortak yanlarının bulunduğu söylenebilir" (2008). Flanagan'a göre bu filmlerde uzun çekimler, sade bir hikâye anlatımı, sükûnete ve gündelik yaşama vurgu vardır (2008). Flanagan sinemadaki bu değişimi kavramsallaştırmanın zamanının geldiğini söyler:

Flanagan'ın bu yazıya "Towards an Aesthetic of Slow in Contemporary Cinema" (Çağdaş Sinemada Yavaşın Estetiğine Doğru) başlığını atması bu konuda daha sonra çalışacak isimlere de öncülük eder. Örneğin Orhan Emre Çağlayan'ın doktora tezindeki bölümlerden biri "An Aesthetics of Boredom"dır (Can Sıkıntısının Estetiği). "Yavaş sinema" ifadesi yerine "yavaşın estetiği" sözüne vurgu yapılması "yavaş" sıfatının tek başına kullanıldığında olumsuz bir değer yargısını belirtiyor olarak algılanmasından olsa gerek. 
Artık soyut bir yavaşlık ifadesi yerine elle tutulur formal ve yapısal bir tasarımın sırası geldi: "Yavaşın estetiği". Bu yönetmenler bize hızlı bir film akışını reddeden, filmsel anlatı beklentimizi değiştiren ve bizi fiziksel olarak yavaş tempodaki filmlere yönlendiren çalışmalar yaptılar (2008).

Flanagan'a göre uzun çekimler sayesinde gözlerimiz görüntüler üstünde daha rahat dolaşır, böylece öykünün içindeki detayları görmemiz ve anlamamız kolaylaşır (2008). Harry Tuttle, Flanagan'ın yazısından bir buçuk yıl kadar sonra "Unspoken Cinema" adlı bloğunda, Flanagan'ın yazısındaki bazı tanımlamalara karşı çıkarak "sanat sinemasını temposuna göre değerlendirmenin faydasız bir çaba olduğunu" söyler (2010a). Tuttle yazısına "Slower or Contemplative?" [Daha Yavaş mı yoksa Düşündüren mi?] ${ }^{3}$ başlığını atarak Flanagan'ın "yavaş sinema" tanımlaması yapmasının eksik olduğunu belirtir:

[...] aslında aynı şeyden bahsediyoruz ama konuya farklı yerden bakıyoruz. Bu filmler yalnızca yavaş değil aynı zamanda sessizdir ${ }^{4}$ de. [...] Bu iki kuramdan tek bir kuram çıkarmak gibi bir zorunluluğumuz olmasa da yavaş ve düşündüren arasındaki gerilimin bu konuşmayı daha verimli kılacağına inanıyorum. Öncelikle yavaş ve düşündüren arasındaki farkı tanımlamalıyız (Tuttle, 2010a).

Tuttle bu nedenle "yavaş sinema" terimini kullanmayı tercih etmez, onun yerine bir süredir kendi kurduğu bloğuna verdiği alt başlıkla "çağdaş düşündüren sinema" der. Bu filmleri yalnızca tempolarına göre adlandırmanın yetersiz olduğunu, filmlerin az diyaloglu olmasının ve izleyiciyle nasıl bir etkileşim kurduğunun da incelenmesi gerektiğini, bu yüzden "yavaş sinema" tanımının yetersiz kaldığını, "düşündüren sine-

"Contemplative cinema" bazı kaynaklarda "tefekkür sineması" (Çam, 2017, s. 25), "irfanî sinema" (Bostan, 2018, s. 49) ya da "irfan sineması" (Güler, 2017) olarak adlandırılır. Semih Kaplanoğlu, Gülçin Şenel'in Buğday filmi üstüne kendisiyle yaptığı bir söyleşide kendi sinemasının "tefekkür" özelliğine vurgu yapar (Şenel, 2018). İslam Ansiklopedisi'nde "Bir şey hakkında iyice düşünmek, bir işin sonucunu hesaplamak" olarak tanımlanan "tefekkür" (bkz. "Tefekkür") sözcüğü, "düşünme" başlığı altında detaylı olarak açıklanır ve "fikr" kökünden türeyen sözcüğün, insanı diğer varlıklardan üstün kılan "akli melekenin kullanılması" olan düşünmeyi karşıladğı ifade edilir (bkz. "Düşünme").

4 Tuttle "konuşmanın olmadığı" anlamına gelen "unspoken" yerine "silence" [sessizlik] sözcüğünü kullanmayı tercih eder. Burada sessizlikten kastı filmlerdeki diyaloğun azlığı ve bu filmlerin ses efekti bombardımanına tutulmamiş olmasıdır (Tuttle, 2010a). 
ma" sözünün kullanılması gerektiğini söyler (2010a). Tuttle'ın görüşlerine kısmen katılsa da Orhan Emre Çağlayan her düşündüren filmin yavaş olmadığının altını çizer (2014, s. 8). Bu konuda Çağlayan'a katılarak Tuttle'ın önermesinin eksik kaldığını düşünüyorum. Örneğin klasik anlatı sinemasinda yer alan Bıçak Sirtı (Blade Runner, Ridley Scott, 1982) filmi Tuttle'a göre düşündüren bir film değil midir? Yıldız Savaşları (Star Wars, George Lucas, 1977) ya da Matrix (The Matrix, Lana ve Lilly Wachowski, 1999) gibi filmlerin düşündürmekten uzak olduğu söylenebilir mi? Nasıl ki "yavaş" ya da "sıkıcı" ifadeleri Tuttle'a göre öznelse bir film için "düşündüren" tanımlaması yapmak da kişisel bir değer yargısını belirtmez mi? Yine Tuttle'ın söylediklerinden yola çıkarsak sessizliğin hâkim olduğu her film düşündüren bir film midir ya da diyaloğun fazla olduğu filmler bu tanımlamaya girmez mi?

Sight \& Sound dergisinin Nisan 2010 sayısında, editör Nick James'in Berlin Film Festivali'nden sonra kaleme aldığı yazı Tuttle ve onunla aynı görüştekileri kızdırır. James, bu yazısında aslında samimi bir itirafta bulunur: Berlin Film Festivali'nde Altın Ayı ödülünü kazanan Semih Kaplanoğlu'nun Bal (2010) filmini izlerken "sıkılmıştır" ve bu yüzden kendini "cahil" hissetmiştir (2010, s. 5). James, bu tür filmlerin anaakım sinemaya karşı "pasif bir saldırganlık" içinde olduğuna vurgu yapar ve artık klişeleşen bu filmlerin festival çevrelerinde ilgi gördüğünü belirtir. James'e göre, bu ilginin sebebi de açıktır: Filmlerde fazla detayın olmaması ve böylece kolayca hatırlanıp, tartışlabilmeleridir (2010, s. 5). Nick James'in bu yazısına en büyük tepkiyi Harry Tuttle, kendi bloğunda yazdıklarıyla verir:

2006'ya, "Çağdaş Düşündüren Sinema"ya (Contemporary Contemplative Cinema) ironik bir şekilde "sıkıcı sanat filmleri" adını verdiğimiz günlere geri döndük. Ama bu kez karşımızdaki anaakım basın değil. Bu sözler Birleşik Krallık'ın sinefil yayıncısından geliyor. Gerçek sinema eleştirmenleri sanata veda ediyor. [...] Peki, o zaman gerçek sanatı kim savunacak (2010b).

Tuttle yakarış şeklinde başlayan yazısında Nick James'e ciddi eleştiriler yöneltir. Öncelikle James'in bu filmleri "yavaş" olarak adlandırmasını, tıpkı Flanagan gibi indirgemeci bulur. Tuttle'a göre yavaşlığa vurgu yapılması bu filmleri aşağılamaktır (2010b). Tuttle, sanatın her zaman perdede gösterilen hakkında olmayacağını bazen de gösterilmeyende gizli olabileceğini, eleştirmenin görevinin de onu bulmak olduğunu söyler: 
Yönetmenlerin görevi siz eleştirmenlerin işini kolaylaştırmak değildir. [...] Bir filmi izlemek için para alıyorsanız, işinizi doğru yapın. [...] Eğer bir filmi izleyecek kadar sabrınız yoksa daha az sabır gerektiren bir iş bulun. [...] Yalnızca başyapıtları izlemek istiyorsanız, film eleştirmenliğini bırakın sadece film eleştirisi okuyun (2010b).

Harry Tuttle'ın yazısından hemen sonra başka bir blog yazarı Steven Shaviro, Tuttle'a karşı Nick James'i savunur. Shaviro, yavaş sinema (ya da Tuttle'ın deyimiyle "çağdaş düşündüren sinema") örneklerinin bazı istisnalar hariç yeni bir şeyler söylemediğine vurgu yapar:

Antonioni'nin tükenmişliği ve can sıkıntısını, Akerman'ın kadınların rutin yaşamlarındaki korkuyu, Janscónun savaşan orduları, Tarkovski'nin sabrı ve zamanı anlatmasında cesur ve provokatif bir şeyler vardı. Tüm bu yönetmenler kendi çaplarında radikaldiler, sinemayı uçlara taşımışlardı. [...] Oysa bugünkü yavaş sinema örnekleri, aksine, cesaretten ve provokasyondan yoksun. Örneğin Dumont ya da Reygadas'ın risk aldığını ya da sinırları zorladığını düşünmüyorum. [...] Adeta rutinleşmiş uzun-çekim, ağır kamera hareketleri, seyrek diyaloglar. [...] Bunlar ciddi sanat sinemasının geçerli uluslararası stili olmuş. Özgünlükten uzak, klişe... (Shaviro, 2010).

Dan Kois, The New York Times Magazine'deki yazısında yllar önce bir arkadaşının, kendisini Tarkovski'nin Solaris (Solyaris, 1972) filmini izlemediği için aşağıladığını ve ona "anlamasan da izlemen gerek" dediğini söyler. Kois, arkadaşının haklı olduğunu, filmi izlemesi gerektiğini, izlediğini ve anlamadığını belirtir (2011). Kois'in filmle ilgili itirafları ilginçtir. Filmde zaman zaman uyuduğunu, gözlerini açtığında acaba kaçırdığı bir şey var mı diye telaşlandığını, sonra her şeyin aynı devam ettiğini görünce rahatladığını, arkadaşının ona filmle ilgili ne düşündüğünü sorduğunda, etkileyici bulduğunu söylediğini, en beğendiği kısım sorulduğunda da aslında en çok sıkıldığı sekans olan beş dakikalık araba sürme sahnesini söylediğini belirtir. Arkadaşı onu başını sallayarak onaylamıştır (2011). Kois yazısının ilerleyen bölümlerinde, bu kadar yavaş ilerleyen filmlerden sıkıldığını, insanların pek çoğunun bu filmleri kendilerini kültürlü hissetmek için izlediğini, kendisinin ise kültüre doyduğunu, ne kadar iүi olursa olsunlar bu "kültür sebzelerini" tüketmek için yaşlandığını itiraf eder (2011). Bu yazı kimileri tarafından alkışlanmışsa da Kois'i eleştiren pek çok yazı yazılmıştır. Kois'e en önemli yanıtlardan biri The New York Times'dan gelir. Manohla Dargis ve A. O. Scott, "In Defense of the Slow and the Boring" (Yavaşı ve Sıkıcıyı Savunmak) başlıklı yazılarında Kois'e 
"sıkıcı olan ne?" diye sorar ve Dargis "Amerika'da ilk beş günde 137.4 milyon dolar hasilat yapan ve tüm sinemalarm \%17'sini kaplayan Felekten Bir Gece Daha (The Hangover Part II, Todd Phillips, 2011) filmini, sürekli tekrarlanan sahneler ve karakterlerin birbirlerine aptalca bakışlarından dolayı çok sıkıcı bulduğunu" söyler. Scott ise "sinemaya neden hep eğlendirmek zorundaymış gibi bakılıyor, 'ciddi' bir film üstüne konuşmak neden insanları tedirgin ediyor" sözleriyle popüler olanın yüceltilmesini eleştirir (Dargis \& Scott, 2011). Kois'i eleştirenlerden biri de David Bordwell'dir:

Örneğin, Tarkovski'nin çağdaşı, Sovyet besteci Sofia Gubaidulina'nın eserlerinin sıkıcı olduğunu belirten bir yazı yazsanız Times bunu yayınlar mı? Hayır, çünkü onun hakkında konuşmak sınırlı ve üst-düzey bir alana girmek anlamına gelir. Pek çok kişi bu müzikten sıkıldığını söyleyebilir ama uzman olmayan birilerinin çağdaş bir besteciyi sıkıcı bulması kimin umurunda? Oysa sinema serbest atı̧̧ alanı tabii, herkesin düşüncesine kulak vermeli (2011).

Bordwell yazısının devamında hızlı tempolu popüler filmlerle yavaş festival filmleri arasındaki kutuplaşmanın tarihçesine değinir, ancak birini sevmenin diğerinden sıkılmayı gerektirmediğini vurgular: "Nasil ki hem Stravinsky hem de rock and roll sevebiliyorsanız, neden hem Hou'yu hem de Spielberg'i sevmeyesiniz?" (2011).

Yavaş sinema tartışmalarının bugüne dek sürdüğüne tanık oluyoruz. Bu tartışmalar yalnızca sinemada değil, yaşamın diğer alanlarında da yavaşlamayı yücelten etkinliklerle sürer. İnsanların müzelerdeki sanat eserlerinin önünden hızlıca geçmelerini önlemek ve bu konuda farkındalık yaratmak için her yıl düzenlenen "Yavaş Sanat Günü" başlığı altındaki etkinliklerde yavaş sinema da konuşulur. ${ }^{5}$ Hızlanan dünyaya karşı yavaşlamak gerektiğine vurgu yapan yavaş şehir ${ }^{6}$, yavaş yemek, yavaş seyahat gibi kavramlar yaygınlaşır. Bütün bu "yavaşlama" hareketi sinemada da kendini gösterecektir.

\section{Yavaş Sinema Anlatısı}

Bir film bize nasıl sunulmaktadır ki biz o filmi yavaş olarak algılarız? Tiago de Luca ve Nuno Barradas Jorge, yavaşlığın kişisel bir değer yargısı olduğunu vurgular (2016, s. 4). Gerçekten de sıkıldığımız anlarda zamanın

Bu konudaki örnek bir söyleşi için bkz. (Kuo, 2012).

Türkiye'deki yavaş şehirler ve yavaş şehir kavramı hakkında bilgi almak için bkz. (Cittaslow Felsefesi, 2019). 
bize daha ağır ilerliyormuş gibi gelmesi hepimizin tecrübe ettiği bir histir. Güzel vakit geçirdiğimizde ise zamanın çok çabuk geçtiğini sanır, hatta "su gibi akıp geçti" tabirini kullanırız. Bir film yavaş olduğu için sıkıcı değildir, sıkıcı geldiği için zaman yavaş ilerliyor gibi görünür. Bu yüzden yavaşlıkla sıkıcılık arasında doğrudan bir ilişki olduğu söylenemez. Buna rağmen, tempoyu düşüren, filmin akışını yavaş olarak algılamamıza neden olan bazı özellikler, "yavaş sinema" kavramının gelişmesine neden olmuştur. Flanagan "uzun çekimin yavaş sinemanin en önemli özelliklerinden biri" olduğunu söyler (2012, s. 4). Bordwell, Tsai Ming-liang, Apichatpong Weerasethakul, Jia Zhangke gibi Asyalı sinemacıları etkileyen Hou Hsiao-hsien sinemasının en önemli özelliğinin uzun çekimler olduğunu vurgular (2015); Tiago de Luca, Carlos Reygadas, Tsai Ming-liang ve Gus Van Sant'ın filmlerinin ortak özelliğinin gerçekliği uzun çekimle sağlamaları olduğunu belirtir (2011, s. 21). Oysa de Luca ve Jorge'ye göre uzun çekimleri olan Hitchcock'un İp (Rope, 1948) filminin yavaş sinema örneği olduğunu söylemek çok da doğru değildir (2016, s. 6). Uzun çekim yavaş sinemanın önemli özelliklerinden biridir; ancak uzun çekimin yer aldığı her film yavaş sinema örneği sayılabilir mi? Öyleyse uzun çekimin dışında başka özelliklere de bakmak gerekir. Çağlayan "gerçekte yavaş olan ne" diye sorar, "kamera ml, oyuncular mı yoksa olayın kendisi mi?" Sonrasındaysa yavaş sinemanın tüm bunların bir bileşkesi olduğunu söyler. Ona göre yavaş sinema "teknik anlamda uzun çekimlerin olduğu, karakterlerinin yavaş hareket ettiği ve ölü zamanın yayıldığı filmlerdir" (Çağlayan, 2018a, s. 7).

Yavaş sinema üstüne yapılan çalışmalardan, bu filmlerin öyküleri ve söylemleri incelendiğinde ortak özelliklerinin olduğu ve bu filmleri yavaş olarak algılamamızda bu özelliklerin birkaçının bir arada bulunmasının rol oynadığı sonucu çıkarılabilir.

\section{Öykü}

Burak Acar'ın Antonioni sineması ile ilgili sözleri, yönetmenin devrimci rolünün altını çizer: "Yerleşik anlatım kalıpları, söyleyeceği 'söz'e dar gelir Antonioni'nin. Onda temsili bir eylem sinemasının izlerini aramak yararsız bir çabadır. Tanık olduğu çağ dramatik örgü bütünlüğünü kaldıramayacak kadar eksilmiş ve parçalanmıştır" (2007, s. 38). Antonioni, filmlerinde, klasik anlatıların gittiği yolda ilerlemez. Seymour Chatman'a göre; 
Klasik anlatılarda olaylar belli bir bölüşümle meydana gelir: her olay bir diğerine neden-sonuç ilişkisiyle bağlıdır, sonuçlar başka sonuçlara neden olurlar. İki farklı olay birbiriyle belirgin bir ilişki içinde görünmese bile, bir ilişki olabileceğini çıkarsarız ve daha genel bir kural olarak bu ilişkiyi daha sonra keşfederiz (2009, s. 42).

Chatman, bu durumu açıklarken Forster'ın Roman Sanatı kitabındaki örneği "Kral öldü ve sonra kraliçe öldü" cümlesini kullanır. Forster, bu cümlenin yalnızca bir öykü olduğunu, oysa "Kral öldü ve sonra üzüntüsünden kraliçe de öldü" cümlesinin bir neden-sonuç ilişkisi taşıdığı için olay örgüsü olduğunu söyler. Forster'a göre "zaman sırası bozulmuş değildir, ama neden-sonuç ilişkisinin varlığı onu gölgelemiştir" (2001, s. 128). Chatman ise insan zihninin daima bir bağlantı aradığını ve aksi söylenmediği takdirde okurların "Kral öldü ve sonra kraliçe öldü" ifadesinde nedensel bir ilişki arayacağını söyler ve bu durumun görsel alanda tutarlılık ararken de olacağını iddia eder (2009, s. 41-42). Chatman'a göre,

"Kral öldü ve sonra kraliçe öldü" ve "Kral öldü ve sonra üzüntüsünden kraliçe öldü" ifadeleri anlatısal olarak sadece yüzeydeki açıklık derecesinde farklllık gösterirler. Daha derin yapısal düzeyde nedensel öge her iki ifadede de yer alır. Okuyucu "anlar" ya da karşılar; kralın ölümünün, kraliçenin ölümünün nedeni olduğunu çıkarsar (2009, s. 42).

André Bazin, Umberto D. (Vittorio de Sica, 1952) filminin "geleneksel film görünümüyle olan herhangi bir ilişkiyi reddettiğini" (2013, s. 211), filmde hiçbir şeyin diğerinden daha üstün olmadığını, Umberto D.'nin senaristi Cesare Zavattini'nin hayalinin doksan dakika boyunca hayatında hiçbir şeyin olmadığı birini anlatan bir film yapmak olduğunu söyler ve Zavattini için Yeni Gerçekçiliğin böyle bir şey olduğuna vurgu yapar (s. 213). Lisandro Alonso'nun Özgürlük (La Libertad, 2001) filmi bir oduncunun yaşamından bir günü anlatır. 73 dakikalık film kurmaca olmasına rağmen belgesel gibidir çünkü her şey çok sıradandır. Alonso, filmleri için, "insanın hayatında üç beş yılda bir karşılaştığı olağanüstü olayla$\mathrm{r} ı$ anlatmayı tercih etmiyorum. İnsan hayatının yarısı kimsenin ilgisini çekmeyen bir sıradanlıkta geçiyor. Bu minimal anları kaydetmeyi tercih ediyorum" der (Falicov'dan aktaran Flanagan, 2012, s. 104).

Kracauer, kurgulanmamış, gerçekte varolan ama keşfedilerek çıkartılabilecek öykülere "buluntu hikâye"7 (found story) adını verir (1997,

"Found story", Aslı Daldal tarafından "bulunmuş öykü" olarak kullanılırken (2003-2004, s. 262), Kracauer'in kitabının 2015'teki çevirisinde "buluntu hikâ- 
s. 245). "Buluntu hikâye", Kracauer'e göre "bir ırmağın ya da gölün yüzeyine uzunca bir süre bakılınca farkedilebilecek rüzgârın oluşturduğu halkalardır" (1997, s. 245). Kracauer, sinemada buluntu hikâyelerin bir bölümünün "basit anlatı" 8 [slight narrative] olduğunu söyler ve Robert J. Flaherty'nin Kuzeyli Nanook (Nanook of the North, 1922) filmini örnek göstererek Flaherty'nin de vurguladığı gibi "öykünün hayatın içinden çıkacağına" inanır (aktaran Kracauer, 1997, s. 247). Aslı Daldal basit anlatının, fotoğrafla içiçe bir sinema olduğunu ve filmin konusunun çoğu kez gündelik yaşantı olduğunu belirtir (2003-2004, s. 263).

Yavaş filmler genelde basit anlatılar içerir. Bu filmlerde dramatik beklentiler genelde boşa çıkar. Lisandro Alonso Liverpool (2008) filminde, uzun süre evinden ayrı kalan bir denizcinin, hasta annesini görmek için köyüne yaptığı yolculuğu anlatır. Köye vardığında yıllar sonra kızını da görür, ama bu karşılaşma herhangi bir dramatik etki yaratmaz. Kız, babasını ilk kez görüyor olmanın yaratabileceği duygusal etkiyi yaşamaz, aksine "bana para ver" der. Baba, kızına Liverpool yazılı anahtarlığı verdikten sonra oradan ayrılır. Benzer bir yolculuk Alonso'nun Ölüler (Los Muertos, 2004) filminde de vardır. Bu kez kızını bulmak için yolculuk eden hapisten çıkan bir adamdır. Filmin sonunda kızının evine ulaşır, ama kızı evde yoktur, torunu oradadır. Yolculuk boyunca herhangi bir "dramatik etki" (aksilikler, engeller) olmadığı gibi yolculuğun sonunda kızıyla karşılaşmadığı için beklediğimiz "dramatik sahne" de yaşanmaz. Alonso'nun derdi aslında gayet sıradan olan bu yolculuğu anlatmaktır.

Anaakım sinemanın sıkça başvurduğu dramatik anlatı yavaş sinemada kırılır. Bunu sağlamak için "ölü zamanlar" ve "rutinlik" kullanılır. Ivone Margulies, Chantal Akerman'ın filmlerini incelediği kitabına Nothing Happens (Hiçbir Şey Olmuyor) adını verir. Margulies'e göre "günde üç öğün yemek hazırlama, yemek yeme, yatak hazırlama ve banyo yapmanın çoğu kez gerçek yaşamdakiyle eşzamanlı gösterildiği" (1996, s. 66) Akerman'ın Jeanne Dielman (1975) filmi "gündelik yaşamın rutinliğini birebir gösterdiği için izleyicinin tahammülünü zorlar ve izleyiciyi rutinlik ve can sıkıntısı üstüne düşünmeye iter" (s. 69). Çağlayan, yavaş sinema yönetmenlerinin Akerman'ın bu rutinlik ve can sıkıntısı tasvirini filmlerinde "estetik bir stratejiye" dönüştürdüğünü belirtir (2014, s. 66). Jim Jarmusch'un Paterson (2016) filmi benzer bir rutinlik içerir. Her gün aynı

ye" ifadesi tercih edilmiştir (Kracauer, 2015, s. 449).

8 "Slight Narrative", "hafif anlatı" olarak da kullanılmaktadır (Kracauer, 2015, s. 451). 
saatte uyanan, köpeğini aynı saatte gezdirmeye çıkaran, aynı saatte bara içkisini içmeye giden Paterson karakteri, rutinin dışına çıkıp karısıyla bir kutlama amacıyla sinemaya gider, eve döndügünde, şiir defterinin köpeği tarafından parçalandığını görür. Böylece Jarmusch, rutin bir yaşam süren karakterini, bunun dışına çıktığı için adeta cezalandırmış olur.

Yavaş sinema filmleri; anlatılarındaki ölü zaman kullanımıyla, klasik anlatıdaki neden-sonuç ilişkilerinin bozulmasıyla, böylece dramatik yapıdan uzaklaşılan sahnelerin bolluğuyla ve gündelik yaşamdaki rutinlerin ve sıradanlıkların temsiliyle birbiriyle benzeşir. Bu anlatılar yabancılaşmış karakterlerinin yaşadığı can sıkıntısının filmin geneline hâkim olduğu hikâyeler içerir. Istırap, sıkıntı, monotonluk ve yabancılaşma bu filmlerin öykü anlatımının en önemli parçaları arasında yer alır. ÖYlece Oturan Bir Fil (Da xiang xi di er zuo, Bo Hu, 2018) filminde, Yu Cheng (Yu Zhang), kendisini terk eden kadınla konuşurken, "hayatım bir çöplük gibi ve çöpler yığıldıkça yığılıyor" der. Kadın da ona yanıt verir: "Herkesin öyle, bunu tek dert edenin sen olduğunu mu sanıyorsun?"

James Quandt, son yıllarda, festivallerdeki sanat sineması örneklerinin genel özelliklerini sıralarken "açıklanmayan bir ıstıraptan" söz eder (2009, s. 76). Rutin bir hayat ve monotonluk filmdeki karakterlerin ruh hallerine yansır. Çağlayan yavaş sinemanın dünyaya karamsar bir gözle baktığını söyler ve filmlerdeki karakterlerin endişe, depresyon, çaresizlik, sıkıntı, yabancılaşma, ruhsal tükeniş gibi durumlar içinde olduklarını vurgular (2014, s. 27). Bu yabancılaşma onları sessiz/içe dönük karakterler haline getirir. Pek çok yavaş filmin diyalog konusunda cimri olduğu söylenebilir. Çağlayan, yavaş sinemada hiçbir şeyin konuşulmadığı anların ölü zamana dâhil olduğunu söyler (2014, s. 67). Ona göre "Tsai Ming-liang'in filmlerindeki sessizlik ve diyalog eksikliği, karakterlerinin anlamsız ve amaçsız olmasından kaynaklıdır. Başka bir deyişle, Tsai Ming-liang'ın karakterlerinin birbiriyle konuşacak fazla bir şeyi yoktur" (2014, s. 151). Béla Tarr Torino Atr (A torinói ló, 2011) filminde baba ve kızı, günlük rutin davranışları sırasında konuşturmamayı tercih eder çünkü ne zaman yemek yeneceği, ne zaman uyunacağı gibi şeyler zaten bellidir, bunları konuşmaya gerek yoktur.

Yavaş sinema filmleri bize her şeyin yolunda olduğu bir dünya sunmaz. Aksine, bu filmlerde çözümsüzlük ve umutsuzluk ön plandadır. Bu yüzden, yavaş sinema örnekleri, sanki aynı hikâyeyi anlatıyor gibi görünür: Karanlık bir dünya, karamsar bir bakış açısı, yolunda gitmeyen pek çok şey, yaşadığı şehre/çevreye yabancılaşmış insanlar, suskun ve 
konuşmamayı tercih eden karakterler. Bu iç karartıcı tabloyu yumuşatabilecek özelliklerden biri mizahtır. Ira Jaffe, Corneliu Porumboiu'nun Bükreş'in Doğusu (A fost sau n-a fost?, 2006) filminin komikliğine vurgu yapar (2014, s. 27), Jarmusch'un Cennetten de Garip (Stranger Than Paradise, 1984) ve Ölü Adam (Dead Man, 1995) filmlerindeki ifadesiz karakterlerin yarattığı mizahtan bahseder (Murphy'den aktaran Jaffe, 2014, s. 31). Pietari Kääpä, Aki Kaurismäki'nin Kalamar Birliği (Calamari Union, 1985) filminin gerçeküstü bir komik-kolaj olduğunu (2010, s. 76), Bir Katil Kiraladım (I Hired a Contract Killer, 1990) filmindeki ana karakter Henry'nin kendini öldürmek için komik denemeler yaptığını (s. 181), Leningrad Kovboyları Amerika'ya (Leningrad Cowboys Go America, 1989) filminin fazla Fin usulü mizah içerdiğini (s. 191), Tatjana (Pidä huivista kiinni, Tatjana, 1994) filminin ise ironiyle nostalji arasında gidip geldiğini (2010, s. 210) söyler. Bütün bu filmler yavaş filmlerdir.

Yavaş sinema, mekân olarak çoğu zaman büyük şehrin kargaşasından uzak yerler seçer. Büyük şehir hayatı hızlıdır, acele etmek gerekir, oysa yavaş sinema karakterlerinin acele etme derdi yoktur. Tsai Ming-liang, kısa filmi Walker'da (2012) karakterini Hong Kong'da hareketli şehrin içinde yavaşlatılmış çekim hızında yürütür. Çevredeki insanlar bu "garip" kişiye dikkatlice bakar. İki yıl sonra Batıya Yolculuk (Xi you, 2014) filminde aynı karakter bu kez Marsilya sokaklarında bir saatlik yolculuğa çıkar. Yine çok yavaştır. Yavaşlık büyük şehirle tezat oluşturur.

\section{Söylem: Sinematografik Özellikler}

Yavaş sinemanın öyküyü nasıl ele aldığının yanında bunu nasıl bir söylemle aktardığı, hangi sinematografik özelliklerin bir filmi yavaş olarak algılamamıza neden olduğu da önemlidir. Karl Schoonover, 60 yıldır sanat filmlerinin birçoğunun seyirciler tarafından yavaş olmakla suçlandığından bahseder (2016, s. 153). Bu şikâyet halinin aslında İkinci Dünya Savaşı'ndan sonra başladığı söylenebilir, çünkü Yeni Gerçekçilikle birlikte sinema alışılmadık bir yola girmiştir. Gilles Deleuze sinemanın İkinci Dünya Savaşı'na kadarki dönemini hareket-imge olarak adlandırır ve "anlık kesit" olarak tanımladığı imgelerin hareketini "sahte" diye nitelendirerek sinemanın sahte hareketin tipik bir örneği olduğunu söyler (2014, s. 12). Film çekimi sırasında yönetmenin çekimi başlatma işareti olarak "hareket/eylem" anlamina gelen "action" - Yerli filmlerde "motor" - sözcüğünü kullanması, ilk ylllarından beri sinemanın hareketle özdeşleşmesinden olsa gerek. Deleuze, bu ilk döneme "montajın" damga vurduğunu söyler; çünkü ona göre "sinemanın evrimi, kendi özünün 
ya da yeniliğinin zaferi, montajla, hareketli kamerayla ve projeksiyondan ayrılan çekimin özgürleşmesiyle gerçekleşecektir" (2014, s. 14). Deleuze, İkinci Dünya Savaşı'ndan sonra ortaya çıkan Yeni Gerçekçilik akımıyla birlikte sinemanın başka bir yöne evrildiğini söyler ve bu döneme "zaman-imge" adını verir. Deleuze'e göre ilk dönemdeki hareketin yerini zaman-imge döneminde "görme sineması" almıştır (2001, s. 2). Hatta Deleuze için perdedeki beden artık hareket etmez, hareketin bir öznesi ya da eylemin aracı olmaz; beden zamanı geliştiren bir unsurdur (2001, s. xi).

Deleuze, Bazin'in Yeni Gerçekçilik üstüne söylediklerinden yola çıkarak sinemanın artık gerçeği temsil etmeyi ya da yeniden üretmeyi değil gerçeği göstermeyi hedeflediğini vurgular (2001, s. 1). Yeni Gerçekçilikle birlikte montajın sinema sanatını biçimlendirmedeki işlevi farklı bir anlam kazanmış, uzun çekim, klasik Hollywood sinemasının çekim sayısı fazla ve kurgusu hızl filmlerine alternatif olarak kullanılmaya başlamıştır. 1950'lerden itibaren gittikçe artan bir yoğunlukta tartışılan uzun çekimden kastedilenin ne olduğunu sorgulamak gerekir. John Gibbs ve Douglas Pye Long Take (Uzun Çekim) adlı kitaba yazdıkları giriş yazısında uzun çekim ifadesindeki uzunluğu sorgular ve bunu belirlemenin çok da kolay olmadığından bahsettikten sonra $(2017$, s. 6) 2001 yılında Donato Totaro'nun yaptığı çalışmayı örnek gösterir. Totaro, Time and the Long Take in The Magnificent Ambersons, Ugetsu, and Stalker başliklı doktora tezinde "bir çekimin uzun çekim olarak adlandırılması için en az 25-40 saniye aralığında olması gerekir" ifadesine yer verir (2001, s. 4). Gibbs ve Pye, iki üç saniyede bir kesmeye alışmış bir izleyici için on saniyenin bile uzun gelebileceğini ifade ederek Totaro'nun bu belirlemeyi yaptığı 2001'den bugüne bu sürenin daha da azalmış olabileceğini vurgular (2017, s. 6). Günümüz sinema teknolojisinin, özellikle Hollywood'un, bazı sahnelerde izleyiciyi neredeyse saniyede bir farklı çekimle buluşturması "yavaşlık" algısını da muhtemelen değiştirmiştir. Bunun yanında, dijital teknoloji artık film bobini değiştirmeden çekim yapmayı olanaklı kıldığından, 1 saat 39 dakika süren Rus Hazine Sandığı (Russkiy kovcheg, Aleksandr Sokurov, 2002) ya da 2 saat 18 dakika süren Victoria (Sebastian Schipper, 2015) gibi filmler sadece tek çekimden oluşabilmektedir. Çağlayan, steadicam ya da el kamerası sayesinde karakterlerin artık takip edilebilir olduğunu, böylece kesmeye gerek kalmadığını ayrıca dijital kayıt teknolojilerinin gelişmesinin daha uzun çekimler yapmayı mümkün kıldığını (2014, s. 54) söyler, ama yavaş sinema söz konusu olduğunda uzun çekimin teknolojik bir yeniliğin ötesinde estetik bir değer olduğunu da vurgular (s. 55). Öyleyse bu estetik değerin neden tercih edildiğini tartış- 
mak, yavaş sinemayı "yavaş" yapan en önemli özelliklerden biri olan uzun çekimin neden kullanıldığını ortaya koymak gerekir.

Bazin'in montaj ve gerçeklik ile ilgili düşüncelerini aktardığı yazılarından biri Jean Tourane'ın Başkalarına Benzemeyen Bir Peri (Une fée... pas comme les autres, 1956) ile Albert Lamorisse'in Krrmızı Balon (Le ballon rouge, 1956) filmini karşılaştırdığı "Montajın Sınırları ve Nitelikleri" başlıklı yazısıdır. Bazin, Tourane'ın filmindeki hayvanların evcil değil yalnızca uysal olduklarını, ortaya çıkan sonucun montaj becerisiyle elde edildiğini söyler ve ekler: "Kurgunun zevkine varmak yerine iyi düzenlenmiş bir gösterinin keyfini çıkarabilirdik. Montaj, izleyicinin talep ettiği gerçeksizliğin durumunu koruyan soyut bir anlam yaratıcısıdır" (Bazin, 2013, s. 57). Bazin, daha sonra Kırmızı Balon filminin gerçekliğini vurgular ve Lamorisse'in kırmızı balonunun bizim ekranda gördüğümüz, kameranın önündeki tüm hareketleri gerçekten yaptığını söyler. Bazin'e göre "görünüm, gerçekliğin kendisi tarafından yaratılmıştır" (Bazin, 2013, s. 57).

Dudley Andrew, Bazin'in asıl derdinin sinemanın gerçeklik üzerine olan bağımlılığı olduğunu vurgular (1995, s. 150). Tiago de Luca ise Bazin'in nesnel gerçekliği manipüle eden Sovyet montajcılarından ya da Alman dişavurumcularından çok mekânı, alan derinliğini ve amatör oyuncuları kullanan yönetmenleri yücelttiğini söyler (2011, s. 15-16) çünkü "Bazin'e göre tıpkı fotoğraf gibi sinemanın da gerçekle ontolojik bir ilişkisi vardır" (s. 15). Uzun çekim, böylece, montaj gibi kişisel bir gerçeklik oluşturmak yerine, gerçeği göstermeyi hedefler. Çinli yönetmen Jia Zhangke de bir söyleşide uzun çekimin gerçek zamanı koruduğunu, böylece zamanın bozulmadığını, anlatmak istediği monotonluğun/çıkmazın böylece daha kolay anlaşılabildiğini söyler (aktaran Flanagan, 2012, s. 86).

Flanagan'a göre yavaş sinemanın belirleyici özelliklerinden biri uzun çekimlerle sağlanan yavaş kamera hareketleridir (2012, s. 63). Çağlayan da yavaş sinemada uzun çekimlerin başat olmasına rağmen, bu filmleri yorumlayan insanların uzun çekimden çok yavaş kamera hareketine vurgu yaptıklarını söyler (2014, s. 55). Çerçevedekilerin yavaşlığı sabit kamera ile ve kameranın yatay çevrinme (pan), dikey çevrinme (tilt) ya da kaydırma hareketlerini yavaş yapmasıyla sağlanır. Kameranın sabitliği ve çevrinme ya da kaydırma hareketlerinin yavaşlığı filmin temposunu da yavaşlatır. Angelopoulos Ulis'in Bakışı (To vlemma tou OdYssea, 1995) filminde Harvey Keitel'ın canlandırdığı A'nın Lenin heykeliyle birlikte nehirde yaptığı yolculuğu yaklaşık on dakika boyunca gösterir. Kafası ve gövdesi parçalanarak gemiye yüklenen Lenin heykelini kıyıda 
bulunan halk istavroz çıkararak selamlar. Angelopoulos, kamerasını bazen gemiye bazen de kıyıya çevirir ve on dakika boyunca bizi bu vedayla baş başa bırakır. Gemi nehirde yavaşça ilerlemektedir. Aslında bu yavaşlık şüphesiz sinemadaki algımızla ilgili bir yavaşlıktır. Gerçek yaşamda da kıyıdan izlediğimizde nehirde ilerleyen bir gemi hızlı gitmez, ancak sinemada olayların bir an önce olup bitmesi beklenir.

Song Hwee Lim de "durağan sinema yalnızca uzun çekimde sabit kalan kamera ile değil, aynı zamanda çekim içinde olanların azlığıyla da sağlanır" (2014, s. 80) diyerek yavaş sinemanın minimalizmle olan bağını vurgular. Yavaş sinemanın "durağanlığı" öne çıkarmasının nedeni ne olabilir? Davis, bu soruya Lim'in ve Jaffe'ın çalışmalarından yola çıkarak yanıt verir: "Lim de Jaffe da yavaş sinemadaki durağanlığın, izleyiciyi filmin dünyasının dışına taşıdığını savunur ve bu zihinsel yolculuk izleyicinin film üstüne, hatta kısa süreliğine, filmin dışındaki konularda düşünmesini sağlar" (Davis, 2016, s. 101). Tsai Ming-liang'ın Sokak Köpekleri filminde hemen önünde duran kadına sarılmak için dakikalarca bekleyen adamla birlikte biz de bekleriz. Nuri Bilge Ceylan'ın Üç Maymun filminde patronunun suçunu üstlenmeden önce şoförün, karısının uyuduğu yatakta oturup düşünmesi bizi de düşündürür. Bu yavaşlık ve durağanlık anlatıyı beyazperdenin dışına taşır, izleyici yalnızca filmde olanı değil belki de kendi yaşamını düşünür.

Bordwell, Angelopoulos'un Yeniden Yaratma ${ }^{9}$ (Anaparastasi, 1970), Kumpanya (O thiasos, 1975), Arıcı (O melissokomos, 1986) ve Puslu Manzaralar (Topio stin omihli, 1988) filmlerinin boş çekimler içerdiğini söyler:

Boş çekimler ayrıca, belirli bir yavaşlık da yaratır. Bu sahneler, izleyicinin algılayabilmesi için, perde üzerinde belirli bir süre kalmak durumundadır ve bu, dramatik ritmin kırılmasına neden olur. İzleyiciler, gördüklerini anlamlandırabilmek için değişik yöntemleri denemek zorundadırlar. Sonuçta, kendine özgü görselliğin ötesinde, bu görüntüler, dramatik ilerlemenin geciktirilmesine ve böylece de derin düşünselliğin gizlenmesine ve kuru, bastırılmış duygusallığa neden olur (2000, s. 110-111).

Luke Andrew Buckle, Abbas Kiarostami sinemasında Yeni Gerçekçiliğin izlerini incelediği çalışmasında gerçekliğin temsili ve gerçek yaşamın nesnel gözlemini önemsediği için Kiarostami'nin Yeni Gerçekçiler

Çeviride Yeniden Yapım ve Yeniden Yapılanma adlarıyla yer almış (Bordwell, 2000). 
gibi uzun ve genel çekimleri tercih ettiğini söyler (2011, s. 21). Mathew Flanagan, uzun çekimlerle birlikte genel çekimin de yavaş sinemanın bir özelliği olduğunu vurgular (2012, s. 23). András Bálint Kovács ise Antonioni'nin gezinen karakterlerinin arka planı olarak manzaraları kullanmasının, onun stilinin en dikkat çekici unsurlarından biri olduğunu söyler (2010, s. 158). Kovács'a göre;

Yeni Gerçekçiler karakterlerini yoksul ve boş arazilerde dolaştırırken bu karakterler, içinde bulundukları ortamdan kopmuştur, karakterler ile çevre arasındaki dramatik gerilim ortadan kalkmış ve iletişimi kesilmiştir. Antonioni filmlerinde ise karakterler, içinde bulundukları çevrenin bir parçasıdır, manzaranın çıplaklığı ile bu manzaranın içinde gezinen karakterlerin ruh halleri arasında bir koşutluk olduğu çok açiktır (2010, s. 158).

Mathew Flanagan, kırsal bir bölgenin görüntülerinden oluşan Danièle Huillet ve Jean-Marie Straub'un yönettiği Trop tôt, trop tard (1981) filmi ile ilgili yorumlardan bahsederken "oraları tadıyorsun, düşünüyorsun" ve "bu filmde bir aktör varsa manzaradır" gibi ifadelerin altını çizerek Kracauer'e gönderme yapar (aktaran Flanagan, 2012, s. 34). Kracauer sinemanın bize gündelik yaşamda fark edilmeyen detayları gösterdiğini söyler ve bir ovanın üstünden geçen bulutun gölgesinin ya da rüzgârda kımıldayan yaprağın tıpkı düşler gibi seyircinin zihnine yerleşeceğini belirtir (1997, s. 52). Yavaş filmlerin şehir yaşamını göstermekten çok kırsal alanlara ve doğaya odaklanması onların önemli özelliklerinden biridir. Özgür Yaren, Kiarostami'nin "pastoral manzaralarından" bahsederken "iç dünyaya yapılan yolculuk kaçınılmaz biçimde kırlardan geçer ve diş gerçekliğin dayanılmazlığına karşı güç toplamamıza yarar" der (2016, s. 18). Yavaş filmlerin bizi kahramanın iç dünyasına götürme çabası, onları şehir yaşamından çok doğada göstermekle daha mümkün hale gelir.

Yavaş sinema tanımlanırken, onun sessizliğine de vurgu yapılır. Örneğin Lim, Tsa Ming-liang sinemasını "durağanlığın, sessizliğin ve yavaşlığın sineması" olarak tanımlar (2014, s. 98). Buradaki "sessizlik" mutlak bir sessizlik değildir. Günümüzde klasik anlatı sinemasındaki gürültülü ses efektlerinin, yoğun diyaloğun ve müziğin azlığı/eksikliği bu filmlerin sessiz olarak tanımlanmasında önemli rol oynar. Buna rağmen bu filmlerin ses kuşağının filmin anlatısında önemli bir role sahip olduğu söylenebilir. Michel Chion, Bresson'un "sesli film sessizliği mümkün kıldı" sözünden yola çıkarak (Chion, 1994, s. 56), sessizliğin bir boşluk olmadığını, daha önceden duyduğumuz ya da hayal ettiğimiz sesin tersi 
olduğunu, başka bir deyişle, bir zitlığın sonucu olduğunu söyler (1994, s. 57). Lim ise Chion'un bu sözlerine karşıllk Ming-liang'ın filmlerindeki sessizliğin işitildiğini vurgular (2014, s. 121). Lim, Ming-liang karakterlerinin, gündelik yaşam ritüellerini gerçekleştirirken, -yemek yerken, uyurken, giyinirken vs.- hep sessiz kaldıklarını oysa örneğin Quentin Tarantino'nun, karakterlerini yalnızken bile konuşturduğunu vurgular (2014, s. 126). Ming-liang'ın karakterleri birlikte oldukları sahnelerde de fazla konuşmaz. Bu yüzden yavaş sinemanın sessiz karakterlerinin, filmin temposunda yavaşlığı sağlayan unsurlardan biri olduğu söylenebilir. Çağlayan görsel anlatı yavaş, durağan ya da monoton olduğunda sesin ön plana çıktığını söyler, böylece ortam sesi belirginleşir. Ortam sesinin sürekli işitilmesi ve ritmik bir gürültünün oluşması, Çağlayan'a göre Béla Tarr'ın yavaş sinemasının başat özelliklerinden biridir (2018b, s. 37). İzleyici bu şekilde, monoton giden yaşamı ya da karakterin sessizliğini daha kolay fark eder. Lim'e göre Tsai Ming-liang'ın "sessiz filmleri" bizi yalnızca izleyici değil, aynı zamanda dinleyici de yapar ve hem görsel hem de işitsel bir dünyayı algılamamıza, düşünmemize neden olur (2014, s. 125). Yavaş sinema karakterlerinin suskunluğu ve filmlerdeki diyalog eksikliği, ortam seslerinin ya da ağlamak, işemek, yemek yemek gibi insan doğasına ait seslerin belirginleşmesine neden olur.

Yavaş sinema filmlerinin yukarıda sayılan bazı ortak yönleri olsa da yönetmenlerin auteur oldukları düşünüldüğünde, filmlerinde kendilerine özgü tarzları benimsemeleri kaçınılmazdır. Bu yüzden her ne kadar yavaş sinema ortak paydasında buluşsalar da yavaş sinema yönetmenlerinin, filmlerini diğer örneklere yaklaştıran ya da onlardan uzaklaştıran özellikleri vardır. Yazının geri kalanında yukarıda sayılan özellikler ışığında Nuri Bilge Ceylan sinemasının yavaş sinemaya ne oranda dâhil olduğunu tartışmaya çalışacağım.

\section{Yavaş Sinema Olarak Nuri Bilge Ceylan Filmleri}

Nuri Bilge Ceylan, bir söyleşide Türkiye'deki bazı eleştirmenlerin Maүıs Sıkıntısı (1999) filmini kaplumbağa ritminde bulduğunu söyler ${ }^{10}$ (Ciment,

1999 yllındaki bir televizyon programında sinema yazarı Ali Hakan, Mayıs Sikıntısı filmini beğendiğini ama filmin ritimsizliğinin ve durağanlığının bazı yerlerde sıkıcı hale geldiğini ve seyirciyi zorladığını, ağır filmlerden hoşlanmayanların, sinemada ritim isteyenlerin bu filmi sevmeyeceklerini söyler. Tuna Erdem ise filmi ağır ve fotoğrafa yakın bulduğunu, filmin temposunun kaplumbağa ritminde olduğunu belirtir (Hakan, Taşçıyan, Açar \& Erdem, 1999). 
2003b, s. 97). Başka bir söyleşideyse "yavaşlığın" göreceli olduğunu, kendi filmini "yavaş" değil, başkalarının filmini "hızlı" diye tanımlamak istediğini belirtir (Alam, 2019, s. 233). Ceylan, ilk uzun filmi Kasaba'dan (1997) son filmi Ahlat Ağacı'na (2018) dek filmlerinin "yavaş" olarak nitelendirilmesini kabul etmiş görünmektedir. Ceylan'ın filmlerindeki öykü ve söylem incelendiğinde "yavaş sinema" içinde nasıl bir yer bulduğunu tartışabiliriz.

\section{Öykü: Sıradan yaşamlar, sıradan öyküler}

Herkes gibi beni çeken konular var tabii ama yine de konu çok önem verdiğim bir şey değil. Her konuda film yapılabilir. İncir çekirdeğinden bile dünyanın en iyi filminin çekilebileceği konusundaki inancım hâlâ değişmedi (Ceylan, 2003, s. 9).

Nuri Bilge Ceylan sineması sıradan olaylar, herkesin hayatında karşılaşabileceği durumlar içerir. Kasaba filminin konusu pek çok kişiye "incir çekirdeğini doldurmayacak kadar önemsiz" gelebilir. Sıradan bir Anadolu kasabası, sıradan bir okul, okuldan eve giden iki kardeş ve evin bahçesinde hayata dair uzun konuşma. Film kasabada yaşayan insanların her gün tanık olduklarını göstermeyi amaçlar. Maүıs Sıkıntısı film çekmek için İstanbul'dan doğup büyüdüğü kasabaya gelen Muzaffer'in (Muzaffer Özdemir) çabasına odaklanır. Klasik anlatı sinemasındaki beklentilerimiz, ortaya çıkabilecek büyük engeller vs. gerçekleşmez, Muzaffer filmini kolayca çeker. Biz onun film çekme sürecine ve çevresindekilerin gündelik sıkıntılarına (babanın kadastrocuları beklemesi, Saffet'in İstanbul'a kaçma isteği, küçük Ali'nin müzikli saat alma çabası) tanık oluruz. Uzak'ta (2002) kasabadan büyük şehre gelen Yusuf (Mehmet Emin Toprak) ile yanına geldiği Mahmut (Muzaffer Özdemir) arasındaki gerilimi, daha çok kişilikleri üzerinden yaşarız. İklimler (2006) bitmiş bir ilişkinin sonrasını anlatır. Bu dört film de pek çok kişinin yaşayabileceği ya da çevresinde tanık olabileceği konuları içerir. Bu özellikleriyle bu filmlerin yavaş sinema yönetmenlerinin tercih ettiği ve daha önceden bahsedildiği gibi Kracauer'in "basit anlatı" olarak tanımladığı filmlerle ortak olduğu söylenebilir. Filmlerdeki karakterler de sıradan, karşılaşabileceğimiz insanlardır. Zaten Ceylan bu filmlerde yakın çevresini oynatır, hatta İklimler'de kendini başrole koyar. Bu filmlerde sert dramatik çatışmalara rastlanmaz. Yaşanan daha çok kişilik çatışmalarıdır. Hatta Ceylan, Uzak filminin senaryosunda önce dramatik çatışmaların çok daha belirgin olduğu sahnelere yer vermiştir. Örneğin senaryoda Mahmut'un komşusu olan bir Fransız cinayete kurban gider. Ceylan, "filmin çok uzayacağını ve 
cinayet sahnesinin filmde bir eksen haline geleceğini, daha önem verdiği yerlerin gölgede kalacağını" düşünerek Fransız'la ilgili tüm sahneleri kurguda atar (Köstepen, Yücel, Okur \& Türk, 2004, s. 197). Belli ki Ceylan, olayların karakterleri anlamamızın önüne geçmesini istemez.

Üç MaYmun'la birlikte Ceylan sinemasında dramatik çatışmaların belirginleştiğine tanık oluruz. Patronu kaza yapınca, onun suçunu üstlenen şoförü ve ailesinin yaşadıkları bir Yeşilçam melodramını aratmaz. Aldatılan koca, kendilerini bu duruma düşüren adamı öldüren gururlu oğlan, hatta zaman zaman düş sahneleriyle ortaya çıkan ölmüş küçük kardeş dramatik çatışmayı diri tutar. Neden-sonuç ilişkilerinin en belirgin olduğu Ceylan filmi belki de Üç Maymun'dur. Sonrasında çektiği Bir Zamanlar Anadolu'da (2011) filmi de öyküyü tıpkı Üç Maүmun'daki gibi bir cinayetten yola çıkarak bize anlatır. Ancak film bize cesedin peşinde olan insanların kişiliklerini, yaşadıkları sıkıntı hallerini göstermeyi tercih eder. Klasik anlatı sinemasında bir gerilim filmi olabilecek konu, bir drama, hatta zaman zaman komediye dönüşür. Karakterlerin sunumu filmi bir cinayet öyküsünden çok bir taşra öyküsüne dönüştürür. Kış $U_{Y^{-}}$ kusu (2014) ve Ahlat Ağacı filmleriyle Ceylan, olayların peşinden gitmeyi bırakır, yeniden bizi insanlık halleriyle buluşturur. Bu filmlerdeki karakterler de sıradan, kendi rutinlerini yaşayan taşra insanlarıdır. Yaşadıkları çatışmalar da, karşılaşılan olaylardan çok doğaları gereği, kişiliklerinden kaynaklanan çatışmalardır.

Ceylan'ın neden-sonuç ilişkilerine bazen bağlı, bazen kopuk ilerleyen filmlerindeki karakterler yaşadıkları yerden/ortamdan bunalmış insanlardır. Kasaba ve Mayıs Sikıntısı'nda Saffet (Mehmet Emin Toprak), Uzak'ta Mahmut (Muzaffer Özdemir), İklimler'de İsa (Nuri Bilge Ceylan), Üç Maymun'da Hacer (Hatice Aslan), Bir Zamanlar Anadolu'da filminde doktor ve savcı (Muhammet Uzuner ve Taner Birsel), Kış UYkusu'nda Aydın ve Nihal (Haluk Bilginer ve Melisa Sözen), Ahlat Ağacı'nda Sinan (Doğu Demirkol) bu durumu en belirgin yaşayanlardır. Çoğu gitmek ister, ama gidemez, bulundukları yeri terk edemez. Hem bu karakterlerin hem de çevrelerindeki diğer karakterlerin taşıdıkları can sıkıntısı film boyunca kendini gösterir. Bu karakterler "yavaş sinemanın" sessiz, bıkkın karakterleriyle neredeyse birebir örtüşür. Bazıları konuşmayı fazla tercih etmez, konuşacak pek bir şey yoktur çünkü. Konuşmak istediklerindeyse, ya İklimler'deki İsa gibi beceremezler ya da Kış UYkusu'ndaki Aydın ya da Ahlat Ağacı'ndaki Sinan gibi kırıp dökerler çünkü konuşmak, hele etkili konuşmak onların bilmediği bir alandır. 
Ceylan'ın filmlerindeki karakterlerin sıkıntısı ve sessizliği ölü zamanlarla desteklenir, böylece dramatik yapının bozulduğuna tanık oluruz. Örneğin Uzak filminin hemen başında Yusuf'un kasabadan ayrıldığı sahne tek plandır ve yaklaşık üç dakika süren bu sahne uzun uzun, kesmeden gösterilir. Mahmut'un televizyon izlediği sahneler gibi pek çok sahnede hiçbir şey olmaz, ancak Ceylan bize bu sahneleri uzun uzun göstermeyi tercih eder. Ali Karadoğan Uzak filminin "ölü zamanları kullanma konusundaki yeteneğini" vurgular (2012, s. 235).

Ceylan çoğu taşrada geçen öykülerini anlatırken bize renkli bir dünya sunmaz. İstanbul'da geçen filmlerinde de şehrin tenha hallerine tanık oluruz. Uzak'ta karla kaplı, çok kolay tanıyamayacağımız bir İstanbul vardır. İklimler'deki İstanbul birkaç sahne dışında kendini belli etmez. Üç MaYmun'daki İstanbul ise varoşlardır, bildiğimiz canlı İstanbul görüntüsünden çok uzaktır. Ceylan bu durum için "Filmlerimdeki İstanbul'un karanlık ve hüzünlü görünmesi, karakterlerimin iç dünyasının bir tezahürü. Ve tabii dolayısıyla benim iç dünyamın bir yansıması" der (Pekçelen, 2016, s. 164).

Nuri Bilge Ceylan'ın filmlerindeki sıkıntı hali, filmlerin taşıdığı mizahla dağılır. Kasaba'daki babanın "Uygarlığın beşiği" ifadesinin İngilizcesini ve Fransızcasını söyleyip Nusaybin'in Türkiye'de olduğunu bilmemesi ve yaptığı bilgiç konuşmalar sırasında burnunu karıştırması izleyicinin gülümsemesine neden olur. Mayıs Sıkıntısı'nda Muzaffer'in kasabalıyla kurduğu diyaloglar ve oluşan tezat komik durumlar yaratır. Örneğin, Pire Dayı'nın evini sorduğunda, köylü kadının "Ne olacaktı?" diye yanıt vermesi üstüne "Cinayet masasından geliyoruz, birkaç sorumuz olacaktı" diyen Muzaffer küçük bir kasabada, yaşını almış bir ihtiyarın evi sorulduğunda şüphe ile yaklaşan kasabalıyı tiye alır. Muzaffer, Saffet'i İstanbul'a gelmemesi için ikna etmeye çalışırken, "İstanbul'da herkes bunalımda, bir iki arkadaş Boğaz Köprüsü'nden atladı" deyince Saffet'in "ben manyak mıyım Boğaz Köprüsü'nden atlayayım" diye yanıt vermesi de mizahi bir durum oluşturur. Bir olaya kasabalı-kentli bakışının ne kadar farklı olabileceği bu diyalogda kendini belli eder. Benzer diyaloglar Uzak'ta da yaşanır. Mahmut'un alaycılığı ve Yusuf'un saflığı izleyiciyi güldürür. Bir camide fotoğraf çekerken Mahmut Yusuf'a "ışığı biraz kaldır" der, Yusuf ayak ayarı yapmak yerine koca lambayı kucaklar. Mahmut'un fareyi yakalamak için kurduğu tuzak konusunda Yusuf'u uyarması ve sonra tuzağa kendisinin yakalanması da Ceylan'ın Mahmut'un alaycıllı̆̆1nı cezalandırmasıdır. 
İklimler'de İsa'nın Bahar'la (Ebru Ceylan) minibüste yalnız kaldığında romantik sözler söyleme çabası, Üç Maymun'da Servet (Ercan Kesal), Hacer'i arabasına almak için durduğunda arkadan korna çalan arabalara sinirlenmesi ve kavga etmek için çıktığında arabada iri yarı adamları görünce korkması mizah içeren sahnelerdir. Bir Zamanlar Anadolu'da, Klş UYkusu ve Ahlat Ağacı filmleri de mizahın özellikle diyaloglarda kendini gösterdiği filmlerdir. Filmlerin taşıdığı mizahla izleyici, yavaş temponun yarattığı durağanlıktan ve karakterin yaşadığı bunaltıcı havadan bir süreliğine kurtulur.

\section{Söylem: "Uzun plan hayattır"}

Ercan Kesal, Bir Zamanlar Anadolu'da filminin senaryosu için yaptıkları toplantılarda Ceylan'ın "ilk sahnenin olabildiğince uzun, tek plan ve kesintisiz çekilmesi gerektiğini" söylediğini aktarır (2018, s. 40). Ceylan Üç Maymun için tuttuğu kurgu günlüğüne de şunları yazar: "Uzun planlarda hemen hayat duygusu ortaya çıkıyor sanki. Kesmeler ve kısa planlar sinema, uzun planlar hayat demek sanki" (2008b s. 16). Ceylan bu sözleriyle gerçeğe yakınlık algısı oluşturduğu için uzun çekimleri tercih ettiğini belli eder.

Yavaş sinema yönetmenlerinin uzun çekimleri tercih ettiğini daha önce söylemiştik. Kullanıcılara filmlerin ortalama çekim uzunluğunu hesaplatarak bir veri tabanı işlevi sunan Cinemetrics sitesine göre bazı filmlerin Ortalama Çekim Uzunlukları (Ortalama Ç. U.) Tablo-1'de gösterilmiştir.

Totaro'nun yukarıda bahsedilen 2001'deki çalışması temel alındığında Antonioni'nin Serüven ve Gece filmleri dışında Tablo 1'de görülen tüm filmlerin uzun çekimler içerdiği söylenebilir. Nuri Bilge Ceylan'ın filmleri bu tabloda kendine nerede yer bulmaktadır? Ceylan'ın sekiz uzun filminin ortalama çekim uzunluğunu belirlemek için filmlerin Bluray/ DVD kopyalarından ölçüm yaptım. Ayrıca karşılaştırma yapılması açısından başkaları tarafından Cinemetrics sitesinde yapılan ölçümleri de Tablo 2'de paylaşıyorum. ${ }^{11}$

Bu tablodan da anlaşılacağı gibi Ceylan'ın İklimler, Üç Maymun ve Uzak filmleri Totaro'nun uzun çekimin süresi olarak 2001'de belirlediği 25 saniye civarındadır. Gibbs ve Pye'ın, bu sayıların günümüzde daha da düşmüş olabileceği, hatta "on saniyenin bile uzun çekim sayılabileceği"

Jenerik süreye dâhil edilmemiştir. 


\begin{tabular}{|l|l|l|c|c|}
\hline Film & Yönetmen & Ölçümü Yapan & $\begin{array}{c}\text { Ölçüm } \\
\text { Tarihi }\end{array}$ & $\begin{array}{c}\text { Ortalama } \\
\text { Ç.U. (sn) }\end{array}$ \\
\hline Torino Atı (2011) & Béla Tarr & Adrian Tomas Samit & 01.11 .2011 & 229.2 \\
\hline $\begin{array}{l}\text { Werckmeister Harmo- } \\
\text { nies (2000) }\end{array}$ & Béla Tarr & Tristan Mentz & 31.01 .2009 & 219.4 \\
\hline Sokak Köpekleri (2013) & Tsai Ming-liang & $\begin{array}{l}\text { Andrea Giudice- } \\
\text { andrea }\end{array}$ & 01.12 .2014 & 102.2 \\
\hline Kurban (1986) & Andrei Tarkovski & Mohsen Nasrin & 22.07 .2011 & 72.3 \\
\hline Liverpool (2008) & Lisandro Alonso & Adrian Tomas Samit & 01.01 .2013 & 65.9 \\
\hline Stalker (1979) & Andrei Tarkovski & Reinier Verhoef & 03.03 .2009 & 63.8 \\
\hline Özgürlük (2001) & Lisandro Alonso & Cid Vasconcelos & 04.05 .2012 & 62.9 \\
\hline Elveda Sinema (2003) & Tsai Ming-liang & Cid Vasconcelos & 12.06 .2009 & 57.9 \\
\hline Serüven (1960) & M. Antonioni & Julian Sittel & 30.03 .2016 & 17.8 \\
\hline Gece (1961) & M. Antonioni & Julian Sittel & 18.02 .2016 & 15.8 \\
\hline $\begin{array}{l}\text { Tablo-1: Bazı filmlerin ortalama çekim uzunlukları. } \\
\text { Cinemetrics sitesinden alınmışır (Erişim Tarihi: 21 Ekim 2019) }\end{array}$ & \\
\hline
\end{tabular}

düşüncesini hesaba kattığımızda Kasaba dışındaki tüm filmlerin uzun çekimler içerdiğini söyleyebiliriz. Buna rağmen Ceylan'ın filmlerinin, yukarıdaki tabloda görüldüğü gibi Béla Tarr, Tsai Ming-liang ve Lisandro

\begin{tabular}{|c|c|c|c|c|}
\hline Film & $\begin{array}{l}\text { Ortalama } \\
\text { Ç.U. [sn] }\end{array}$ & $\begin{array}{l}\text { Cinemetrics } \\
\text { ölçümü }\end{array}$ & $\begin{array}{c}\text { Cinemetrics } \\
\text { Ölçümünü } \\
\text { Yapan }\end{array}$ & $\begin{array}{l}\text { Cinemetrics } \\
\text { Ölçüm Tarihi }\end{array}$ \\
\hline İklimler (2७७6] & 29,03 & 28,8 & Cagri Inceoglu & 05.01 .2015 \\
\hline Üç Maymun (2००८] & 25,62 & $\begin{array}{c}\text { Ölçümm } \\
\text { yapılmamıştır }\end{array}$ & - & - \\
\hline Uzak (2००2) & 24,64 & 23,7 & Cagri Inceoglu & 2०.०8.2015 \\
\hline Bir Zamanlar Anadolv'da (2011] & 19,80 & 19,1 & Cagri Inceoglu & 26.08 .2015 \\
\hline Mayıs Sıkıntısı (1999] & 14,22 & 14,1 & Cagri Inceoglu & 15.09.2015 \\
\hline Kış Uykusu [2014] & 11,98 & $\begin{array}{c}\text { Ölçüm } \\
\text { yapılmamıştır }\end{array}$ & - & - \\
\hline Ahlat Ağacı (2७18) & 11,21 & $\begin{array}{c}\text { Ölçüm } \\
\text { yapılmamıştır }\end{array}$ & - & - \\
\hline Kasaba (1997) & 9,25 & 9,4 & Cagri Inceoglu & 25.12.2014 \\
\hline
\end{tabular}


Alonso gibi yavaş sinema dendiğinde akla gelen ilk yönetmenler kadar uzun çekimlere sahip olmadığı görülmektedir. Ceylan'ın filmleri Tarkovski kadar uzun çekimler de içermemekte, çekim uzunluğu söz konusu olduğunda Antonioni filmleri ile benzeşmektedir.

Ortalama çekim uzunluğunun yanı sıra filmin içinde yer alan uzun çekimler de filmin "yavaş" algılanmasına neden olabilir. Tablo-3'te Ceylan'ın sekiz uzun filmindeki en uzun çekimlerin süresi gösterilmektedir.

Bu tablodan da anlaşılacağı gibi Ceylan'ın uzun çekimleri en az kullandığı filmlerinden biri olarak kabul edilebilecek Kış UYkusu'nda bile iki dakikayı aşan çekimler yer almaktadır. Başka bir deyişle kamera iki dakika boyunca hiçbir kesme olmadan ilerlemektedir. İklimler'de bu sayının beş buçuk dakikayı aştığına tanık oluruz. Her ne kadar ortalama çekim uzunluğu diğer yavaş sinema yönetmenleri kadar uzun olmasa da filmlerdeki bazı sahnelerin epeyce uzun çekimler içermesi bu filmleri "yavaş" olarak algılamamiza neden olabilir.

Uzun çekimin filmlerin yavaş olarak algılanmasında önemli olduğunu, ancak kameranın yavaş hareketinin de yavaşlığa katkı sunduğunu daha önce söylemiştik. Ceylan'ın filmlerinde de kameranın yavaş hareketine tanık oluruz. Bu yavaş kamera hareketleri birkaç istisna içerir. Maүıs Sıkıntısı'nda Ali'nin (Muhammed Zımbaoğlu) kümesten yumurta çaldığı sahne, babanın pazar yerinde kadastrocuları aradığı sahne, İklimler'de motosikletin devrildiği sahne, Kış UYkusu'nda arabanın camına taş atıldığı sahne, Ahlat Ağacı'nda Sinan'ın evde parasının çalındığı sahne gibi bazı yerlerde hızlı çevrinmelere rastlanır. Ancak bunlar filmde çok kısa

\begin{tabular}{|l|c|c|}
\hline Film & Ortalama Ç.U. (sn) & En Uzun Çekim (sn) \\
\hline İklimler (2006) & 29,03 & 332 \\
\hline Üç Maymun (2008) & 25,62 & 169 \\
\hline Uzak (2002) & 24,64 & 192 \\
\hline Bir Zamanlar Anadolv'da [2011) & 19,80 & 181 \\
\hline Mayıs Sıkıntısı (1999) & 14,22 & 178 \\
\hline Kış Uykusu (2014) & 11,98 & 121 \\
\hline Ahlat Ağacı (2018) & 11,21 & 223 \\
\hline Kasaba (1997) & 9,25 & 146 \\
\hline Tablo-3: Nuri Bilge Ceylan Filmlerinin ortalama çekim uzunluğu ve en uzun çekimin süresi. \\
\hline
\end{tabular}


süren sahnelerdir. Onun dışında Ceylan kamerasını ya sabit tutar ya da çok yavaş hareket ettirir.

Yavaş sinema yönetmenlerinin yakın çekimleri tercih etmeyip, genel çekim kullanmalarının, onların gerçekçiliği vurgulama kaygılarından olduğunu söylemiştik. Kasaba'da Ceylan'ın ayrıntı çekimlere yer verdiğini, bunu yaparken yalnızca insanların yüzlerini ya da gözlerini, kulaklarını değil, doğayı da (yapraklar, eşeğin gözü, kaplumbağa gibi) kullandığına tanık oluruz. Mayıs Sikıntısı'nda Kasaba'daki kadar olmasa da yine yakın çekimlere sıkça rastlanır. Ayrıntı çekimler ise yok denecek kadar azdır. Filmden sonra yapılan bir söyleşide Ceylan "bu filmde daha önceki filmlere göre daha az yakın plan kullandım. Yakın plan olabilir tabii, mesela Bergman sineması bayağı yakın plana dayanır, ama yakın planın iyi bir gerekçesi olması lazım" der (Göktürk \& Çapan, 2003, s. 102).

Uzak, Ceylan'ın önceki filmleriyle kıyaslandığında yakın çekimleri daha az kullandığı bir filmdir. Yakın çekimler daha çok, daha duygusal olan Yusuf'un yüzüne yapılır. Hasan Akbulut, Uzak filminde Nuri Bilge Ceylan'ın kamerasının tıpkı filmin adı gibi, kendisi ile kaydettiği kişiler ya da nesneler arasında belli bir uzaklık bıraktığını söyler (2005, s. 32). Ceylan benzer tavrı İklimler'de de gösterir. Filmde Bahar rolündeki Ebru Ceylan yakın planda olduğu ve filmde kullanılmayan bir görüntüsüyle ilgili düşüncesi sorulduğunda şu yanıtı verir:

Filmin başlarındaki arkadaşlarla akşam yemeği sahnesi aslında değişik açılardan çok versiyonlu çekildi. [...] dramatik etkiyi vurgulayan birçok yakın plan çekim yapıldı. Ama Bilge kurguda yine her zamanki gibi, tek bir genel plandan oluşan versiyonunu tercih etti. Artık iyice anlamış bulunuyorum ki Bilge, ne hayatta ne de sinemada hiçbir duygunun gereğinden fazla altının çizilmesinden ya da abartılmasından hoşlanmiyor (Ceylan, 2009, s. 205).

$\mathrm{Bu}$ sözlere rağmen filmdeki yakın çekimlerin daha çok Bahar'ın görüntüleri olduğu söylenebilir. Ceylan, filmde daha olumsuz yansıttığı İsa'ya ya da Serap'a (Nazan Kesal) kamerasını uzak tutar.

Ceylan Üç MaYmun'da yakın çekimlere Uzak ve İklimler'dekinden daha sık başvurur. Hatta özellikle erkek karakterlerin yaşadığı sıkıntıyı anlatmak için ayrıntı çekimlere de rastlanır. Kendisine bu filmde neden daha fazla yakın plan çektiğiyle ilgili bir soru yöneltildiğinde Ceylan, bunun farkında olmadığını, çalıştıkları evin çok küçük olduğunu, kamerayı çok uzağa götürme şansının fazla olmadığını, özellikle filmin ikinci yarı- 
sında, tüm anlamı bakışlarla ortaya çıkarmaya çalıştığı için yakın çekime ihtiyaç duymuş olabileceğini söyler (Yücel, 2012, s. 363).

Bir Zamanlar Anadolu'da, Kış Uүkusu ve Ahlat Ağacı gibi diyalogların fazla olduğu filmlerde de yakın çekimlere rastlarız. Ceylan karşılıklı konuşmaların olduğu sahnelerde amors çekimleri kullanmayı tercih eder. Böylece çerçevede sağladığı hiyerarşiyi, çekim ölçeğiyle de pekiştirir. Genelde dinleyen kişinin omzundan yapılan çekimle konuşan kişiyi daha net görür, flu bir şekilde omzu görünen kişiyi yalnızca hissederiz. Ceylan, konuşmaların yarattığı duygusal atmosferi daha yakından hissetmemizi sağlamak içinse ayrıntı çekimlere yer verir.

Ceylan'ın filmlerindeki ses tasarımı ayrı bir yazının konusudur, ancak yavaş sinema bağlamında incelendiğinde filmlerinin doğal sesleri fazlasıyla yansıtması Ceylan'ı yavaş sinema yönetmenlerine yaklaştırır. Daha önce yavaş sinemanın, insan sesinin eksikliğinden doğan boşluğu abartılı efekt kullanımıyla doldurduğundan bahsetmiştik. Bu durum, Ceylan'ın filmleri için de geçerlidir. Ceylan'ın taşrada geçen filmlerinde doğanın sesleri baskındır. Rüzgârın, yağmurun, gök gürültüsünün, fırtınanın, ağaçların sesleri kendini fazlasıyla hissettirir. Kasaba ve Maүıs Sıkıntısı konuşmanın da az olduğu filmler olduğundan karakterlerin seslerinden çok doğanın sesini duyarız. Ahlat Ağacı'nda köpek havlaması, çakal uluması sohbetlere karışır. İklimler'in ve Kış UYkusu'nun başında abartılı bir sinek vızıltısı sesi vardır. Alam'ın da belirttiği gibi Ceylan doğanın seslerinin kendisine müzik gibi geldiğini söyler (2019, s. 231). Ceylan İstanbul'un da seslerini yoğun bir şekilde kullanmaktan kaçınmaz. Uzak'taki gemi düdüğü, İstiklal Caddesi'ndeki kalabalığın gürültüsü, Üç Maymun'daki tren sesi zaman zaman kendini hissettirir. Ceylan gündelik yaşamın vazgeçilmezi olan televizyon seslerini de filmlerde bize duyurur. Bazen ekranlarını görür, görmediğimiz zamanda da televizyondaki filmin ya da haberlerin sesini duyarız.

\section{Sonuç}

2000'li yıllarla birlikte tanımlanmaya başlayan "yavaş sinema", karakterlerinin genelde sıkıntı hallerinin yansıtıldığı, klasik anlatı sinemasındaki dramatik çatışmalardan uzak, gündelik yaşamın rutinlerine vurgu yapan filmler içerir. Bu öykü evreni uzun çekimlerle ve yavaş kamera hareketleriyle desteklenerek tempoda bir yavaşlığın hissedilmesine neden olur. Nuri Bilge Ceylan filmlerinin öyküleri incelendiğinde genel hatlarıyla yavaş sinemaya yakın olduğu söylenebilir. Filmlerdeki sıkıntı hali, karak- 
terlerin genel özellikleri ve mekân tercihleri filmleri "yavaş sinema" olarak değerlendirmemizi sağlar. Ancak karakterlerin sessizliği, dramatik çatışmaların belirginliği düşünüldüğünde klasik anlatı sinemasına yaklaşan filmleri olduğu sonucuna da varabiliriz. Üç Maymun'dan itibaren dramatik çatışmalar belirginleşir, Bir Zamanlar Anadolu'da filminden itibaren ise karakterler daha konuşkan olur. Buna rağmen bu filmleri yavaş sinemadan klasik anlatı sinemasina giden yolda yer alan filmler olarak değerlendirmek daha doğru olacaktır.

Söylem/sinematografi açısından incelendiğinde Ceylan'ın filmlerinin yavaş sinemanın örnekleri olduğu iddia edilebilir. Bu filmlerin hepsi yavaş kamera hareketleri içeren, çekimlerin genelde uzun olduğu, karakterler sessizleştiğinde doğanın sesinin ön plana çıktığı filmlerdir. Her ne kadar Kasaba, Kış UYkusu ve Ahlat Ağacı filmleri Ceylan'ın diğer filmleriyle karşılaştırıldığında ortalama çekim uzunluğu bakımından daha kısa süreler içerse de bu filmler klasik anlatı sinemasındaki kısa çekim sürelerine yaklaşmaktan epeyce uzaktır. Yine de Kış UYkusu ve Ahlat Ağacı ile birlikte Ceylan sinemasının kısmen hızlandığı iddia edilebilir. Bu filmlerde Ceylan hem karakterlerini daha çok konuşturmaya, hem dramatik çatışmayı artırmaya, hem de kurguda daha sık kesmeye başvurmaya başlamıştır. Ancak bu iki film de üç saatten uzun sürer. Sürenin uzaması, izleyicide sıkılma duygusunu tetikleyebilir, bu da filmin yavaş olduğu algısına neden olabilir. Şu soru sorulabilir: Bu filmler üç saat değil de bir buçuk saat sürseydi yine "yavaş" yorumu yapılır mıydı? Bu sorunun yanıtını vermek kolay değil, ama Ceylan'ın sekiz uzun filmini göz önünde bulundurduğumuzda Kış Uүkusu ve Ahlat Ağacı'nın diğer filmleriyle kıyaslandığında daha "hızlı" olduğu, genel özellikleriyle yavaş sinemadan etkiler taşısalar da yavaş sinemaya örnek verilecek filmler olarak kabul edilemeyecekleri söylenebilir.

\section{Kaynakça}

Acar, B. (2007). Antonioni'ye Veda. Altyazı, 65, 38-40.

Akbulut, H. (2005). Nuri Bilge Ceylan Sinemasinı Okumak: Anlatı, Zaman, Mekân. İstanbul: Bağlam.

Alam, M. (2019). Meselem İnsan Denilen Muamma... Nuri Bilge Ceylan'la söyleşi. N. B. Ceylan (Ed.), Bir Zamanlar Anadolu'da (s. 219-244). 
İstanbul: Doğan Kitap. [Söyleşi 6 Ekim 2011 tarihinde Mithat Alam Film Merkezi'nde gerçekleştirilmiştir].

Andrew, J. D. (1995). Büүük Film Kuramları (Çev. İ. Şener). İstanbul: Sistem.

Bazin, A. (2013). Sinema Nedir? (Çev. İ. Şener). İstanbul: Doruk.

Bordwell, D. (2000). Modernizm, Minimalizm, Melankoli: Theo Angelopoulos ve Görsel Biçim (Çev. A. Ufuk). Yeni İnsan Yeni Sinema, 7, 102-122.

Bordwell, D. (2011, 10 Temmuz). Good and Good For You. David Bordwell's Website On Cinema. http://www.davidbordwell.net/ blog/2011/07/10/good-and-good-for-you/ (Erişim Tarihi: 25 Şubat 2019).

Bordwell, D. (2015). Hou Hsiao-hsien: Constraints, Traditions and Trends. https://vimeo.com/129943635 (Erişim Tarihi: 5 Mart 2019).

Bostan, M. (2018). Buğday ve "İrfani Sinemanın" Geleceği. Faryap, 104, 49-51. https://www.academia.edu/35836460/Bu\%C4\%9Fday_ ve_\%C4\%Borfani_Sinema_n\%C4\%Bın_Gelece\%C4\%9Fi (Erişim Tarihi: 14 Eylül 2019).

Buckle, L. A. (2011, Aralık). Contemporary Neorealist Principles in Abbas Kiarostami's Filmmaking (1997-2005) (Yayınlanmamış Yüksek Lisans Tezi). University of Hertfordshire, Hertfordshire.

Ceylan, E. [Ebru]. (2009). Fotoğraflarla Kamera Arkası Yorumları: Ayazda İki Yürek. N. B. Ceylan (Ed.), İklimler (s. 203-207). İstanbul: Norgunk. [Yazı ilk olarak Ekim 2006'da Film Artı dergisinde yayınlanmiştır]

Ceylan, N. B. (Yönetmen). (1997). Kasaba [Film]. Türkiye: NBC Film.

Ceylan, N. B. (Yönetmen). (1999). Maүıs Sıkıntısı [Film]. Türkiye: NBC Film.

Ceylan, N. B. (Yönetmen). (2002). Uzak [Film]. Türkiye: NBC Film.

Ceylan, N. B. (2003, Mayıs). "Sanki Her şey Kendiliğinden Oluyor Gibi". Sonsuzkare, 1, 9.

Ceylan, N. B. (Yönetmen). (2006). İklimler [Film]. Türkiye-Fransa: Pyramide Films-Co Production-Imaj-NBC Film.

Ceylan, N. B. (Yönetmen). (2008). Üç Maymun [Film]. Türkiye-Fransa-İtalya: Zeynofilm-NBC Film-Pyramide Productions-BIM Distribuzione. 
Ceylan, N. B. (2008). Üç Maymun Kurgu Günlüğü. [Altyazı Aүllk Sinema Dergisi'nin ücretsiz eki]. İstanbul.

Ceylan, N. B. (Yönetmen). (2011). Bir Zamanlar Anadolu'da [Film]. Türkiye-Bosna-Hersek: Zeynofilm vd.

Ceylan, N. B. (Yönetmen). (2014). Kış UYkusu [Film]. Türkiye-Fransa-Almanya: Zeynofilm vd.

Ceylan, N. B. (Yönetmen). (2018). Ahlat Ağacı [Film]. Türkiye vd: Zeynofilm vd.

Chatman, S. (2009). Öүkü ve SöYlem: Filmde ve Kurmacada Anlatı Yapısı (Çev. Ö. Yaren). Ankara: Deki.

Chion, M. (1994). Audio-vision: Sound On Screen. New York: Columbia University Press.

Ciment, M. (2003a). Michel Ciment: The State of Cinema. http:// web.archive.org/web/20040325130014/http:/www.sfiff.org/festo3/ special/state.html (Erişim Tarihi: 23 Şubat 2019).

Ciment, M. (2003b). "Bir Tema Üzerine Çeşitlemeler Hoşuma Gidiyor..." Nuri Bilge Ceylan'la söyleşi. N. B. Ceylan (Ed.), Maүıs Sıkıntısı: Senaryo (s. 91-99). İstanbul: Norgunk. [Söyleşi ilk olarak 13 Mayıs 2000 tarihinde gerçekleştirilmiş, Nisan 2001 tarihinde Positif dergisinin 482. sayısında yayınlanmıştır].

Cinemetrics. (2019). Cinemetrics Database. http://www.cinemetrics. lv/database.php (Erişim Tarihi: 12 Ekim 2019).

Cittaslow Felsefesi. (2019). https://cittaslowturkiye.org (Erişim Tarihi: 31 Mart 2019).

Çağlayan, O. E. (2014). Screening Boredom: The History and Aesthetics of Slow Cinema. (Doktora Tezi). University of Kent, Kent. (Sonradan yayınlandl)

Çağlayan, O. E. (2018a). Poetics of Slow Cinema: Nostalgia, Absurdism, Boredom. Cham: Palgrave Macmillan.

Çağlayan, O. E. (2018b). Sounds of Slowness: Ambience and Absurd Humour in Slow Sound Design. The New Soundtrack, 8(1), 31-48.

Çam, A. (2017). Dünyanın Sonu ya da Torino Atı'nın Bazı Planları Hakkında. Duvar, 29, 24-29. https://www.academia.edu/34363643/A_ torinoi_lo (Erişim Tarihi: 14 Eylül 2019). 
Daldal, A. (2003-2004, Kasım-Aralık-Ocak). Gerçekçi Geleneğin İzinde: Kracauer, "Basit Anlatı" ve Nuri Bilge Sineması. Doğu Batı, 25, 255-273.

Dargis, M. \& Scott, A. O. (2011, 3 Temmuz). In Defense of the Slow and the Boring. The New York Times. https://www.nytimes. com/2011/06/05/movies/films-in-defense-of-slow-and-boring. html (Erişim Tarihi: 23 Şubat 2019).

Davis G. (2016). Stills and Stillness in Apichatpong Weerasethakul's Cinema. T. de Luca \& N. B. Jorge (Ed.), Slow Cinema (s. 99-111). Edinburgh: Edinburgh University Press.

de Luca, T. (2011). Realism of The Senses: A Tendency In Contemporary World Cinema. (Yayımlanmamış Doktora Tezi). University of Leeds, Leeds.

de Luca, T. \& Jorge, N. B. (2016). Introduction: From Slow Cinema to Slow Cinemas. T. de Luca \& N. B. Jorge (Ed.), Slow Cinema (s. 1-21). Edinburgh: Edinburgh University Press.

Deleuze, G. (2001). Cinema 2: The Time-Image (6th Edition). Minneapolis: University of Minnesota.

Deleuze, G. (2014). Sinema 1: Hareket-İmge (Çev. S. Özdemir). İstanbul: Norgunk.

Düşünme. Türkiye Diyanet Vakfı İslam Ansiklopedisi https://islamansiklopedisi.org.tr/dusunme (Erişim Tarihi, 14 Eylül 2019).

Flanagan, M. (2008, Kasim). Towards an Aesthetic of Slow in Contemporary Cinema. 16:9. http://www.16-9.dk/2008-11/sidell_inenglish.htm (Erişim Tarihi: 3 Şubat 2019).

Flanagan, M. (2012). 'Slow Cinema': Temporality and Style in Contemporary Art and Experimental Film. (Yayımlanmamış Doktora Tezi). University of Exeter, Exeter.

Forster, E. M. (2001). Roman Sanatı (3. Baskı) (Çev. Ü. Aytür). İstanbul: Adam.

Gibbs, J. \& Pye, D. (2017). Introduction 1: The Long Take: Critical Approaches. J. Gibbs \& D. Pye (Ed.), The Long Take (s. 1-26). Londra: Palgrave.

Göktürk, Y. \& Çapan, S. (2003). Böbrek denince... Nuri Bilge Ceylan'la söyleşi. N. B. Ceylan (Ed.), Mayıs Sıkıntısı: Senaryo (s. 101-117). 
İstanbul: Norgunk. [Söyleşi ilk olarak Ocak 2000 tarihindeki Roll dergisinin 38. sayısında yayınlanmıştır].

Güler, A. (2017, 24 Kasım). Bir İlim-Kurgu filmi: Buğday. Mücerret. http://www.mucerret.com/yazarlar/bir-ilim-kurgu-filmi-bugday/\#comments (Erişim Tarihi: 14 Eylül 2019).

Hakan, A., Taşçıyan, A., Açar, M. \& Erdem, T. (Sunucu). (1999). Beyazperde [Televizyon Programi]. İstanbul: NTV. https://www.youtube. com/watch?v=W92X2y92Wvg\&list=PLtYl4zY2IjHV_aIdjcTMsQUcHS2abN3sc\&index=2 (Erişim tarihi: 22 Şubat 2019).

Jaffe, I. (2014). Slow Movies: Countering the Cinema of Action. New York: Wallflower Press.

James, N. (2010, Nisan). Passive Agressive. Sight \& Sound, 20(4), 5.

Kääpä, P. (2010). The National and Beyond: The Globalisation of Finnish Cinema in the Films of Aki and Mika Kaurismäki. Almanya: Peter Lang.

Karadoğan, A. (2012). Sanat Sinemasına Uzak'tan Bakmak. S. Büker ve S. R. Öztürk (Ed.), Sinemada Hayat Var (s. 229-241). Ankara: Deki. Kesal, E. (2018). Evvel Zaman (2. Baskı). İstanbul: İletişim.

Kois, D. (2011, 29 Nisan). Eating Your Cultural Vegetables. The New York Times Magazine. https://www.nytimes.com/2011/05/o1/magazine/mag-01Riff-t.html (Erişim Tarihi: 23 Şubat 2019).

Kolver, S. G. (2018, 3 Ağustos). Nuri Bilge Ceylan: Gıcık karakterlerle uğraşmayı seviyorum. Nuri Bilge Ceylan'la Söyleşi. Cinedergi. http://www.cinedergi.com/2018/08/03/nuri-bilge-ceylan-gicik-karakterlerle-ugrasmayi-seviyorum/ [Bu söyleşi 2014'te gerçekleştirilmiştir]. (Erişim Tarihi: 12 Ekim 2019).

Kovács, A. B. (2010). Modernizmi Seyretmek: Avrupa Sanat Sineması (1950-1980) (Çev. E. Yılmaz). Ankara: Deki.

Köstepen, E., Yücel, F., Okur, Y. \& Türk, İ. (2004). Sinema Pratiğini Fotoğrafa Benzetmeye Çalışıyorum. Nuri Bilge Ceylan'la söyleşi. N. B. Ceylan (Ed.), Uzak (s. 197-207). İstanbul: Norgunk. [Söyleşi ilk olarak Altyazı dergisinin Şubat 2003 tarihli 15. sayısında yayınlanmiştır].

Kracauer, S. (1997). Theory of Film: The Redemption of Physical Reality. New Jersey: Princeton. 
Kracauer, S. (2015). Film Teorisi: Fiziksel Gerçekliğin Kurtuluşu (Çev. Ö. Çelik). İstanbul: Metis.

Kuo, N. (2012). A Cinematic Approach to Slow Art With Nadin Mai. Slow Art Day. http://www.slowartday.com/a-cinematic-approachto-slow-art-with-nadin-mai/ (Erişim Tarihi: 25 Şubat 2019).

Lim, S. H. (2014). Tsai Ming-liang and a Cinema of Slowness. Honolulu: University of Hawai'i Press.

Margulies, I. (1996). Nothing Happens: Chantal Akerman's HYperrealist Everyday. Durham ve Londra: Duke University Press.

Pekçelen, S. (2016). "Oyuncularla İlişkim Biraz Hastalıklıdır". Nuri Bilge Ceylan'la Söyleşi. N. B. Ceylan (Ed.), Söyleşiler (2. Baskı) (s. 16o164). İstanbul: Norgunk. [Söyleşi Ekim 2008'de Time Out (İstanbul) dergisinde yayınlanmıştır].

Quandt, J. (2009). The Sandwich Process: Simon Field Talks About Polemics and Poetry at Film Festivals. Richard Porton (Ed.), Dekalog 3: On Film Festivals (s. 53-80). Londra: Wallflower Press.

Schoonover, K. (2016). Wastrels of Time: Slow Cinema's Laboring Body, the Political Spectator, and the Queer. T. de Luca ve N. B. Jorge (Ed.), Slow Cinema (s. 153-168). Edinburgh: Edinburgh University Press.

Shaviro, S. (2010, 12 May1s). Slow Cinema vs Fast Films. The Pinocchio Theory. http://www.shaviro.com/Blog/?p=891 (Erişim Tarihi: 23 Şubat 2019).

Şenel, G. (2018, 5 Mayı). Semih Kaplanoğlu ile Hayat, Sinema ve "Buğday" Üzerine. Akademya. https://akademyadergisi.com/semih-kaplanoglu-ile-hayat-sinema-ve-bugday-uzerine/ (Erişim Tarihi: 14 Eylül 2019).

Tefekkür. Türkiye Diyanet Vakfı İslam Ansiklopedisi. https://islamansiklopedisi.org.tr/tefekkur (Erişim Tarihi, 14 Eylül 2019).

Totaro, D. (2001). Time and the Long Take in The Magnificent Ambersons, Ugetsu, and Stalker. (Yayınlanmamış Doktora Tezi). University of Warwick, Warwick.

Tuttle, H. (2010a, 17 Mart). Slower or Contemplative? Unspoken Cinema. http://unspokencinema.blogspot.com/2010/03/slower-or-contemplative.html (Erişim Tarihi: 23 Şubat 2019). 
Tuttle, H. (2010b, 12 Mayıs). Slow Films Easy Life. Unspoken Cinema. http://unspokencinema.blogspot.com/2010/05/slow-films-easy-life-sight.html (Erişim Tarihi: 23 Şubat 2019).

Yaren, Ö. (2016). Kiarostami'nin İzleri. Altyazı, 164, 18-20.

Yücel, F. (2012). "Gerçek, Sakladığımız Tarafta". Nuri Bilge Ceylan'la Söyleşi. N. B. Ceylan (Ed.), Üç Maymun (s. 355-365). İstanbul: Doğan Kitap. [Söyleşi ilk olarak Ekim 2008'de Altyazı dergisinde yayınlanmiştır]. 
